\title{
Bone Mineral Density in Patients With Early- Onset Rheumatoid Arthritis ${ }^{\S}$
}

\author{
Erken Başlangıç Romatoid Artritindeki Hastalarının Kemik Mineral Yoğunluğu
}

\author{
Sylejman Rexhepi ${ }^{1 \oplus}$, Mjellma Rexhepi $^{1} \oplus$, Blerta Rexhepi $^{1} \oplus$, Vjollca Sahatciu-Meka ${ }^{2} \oplus$, Vigan Mahmutaj ${ }^{3} \oplus$ \\ ${ }^{1}$ Rheumatology Clinic, University Clinical Centre of Kosova, Kosova \\ ${ }^{2}$ University of Prishtina, Kosova \\ ${ }^{3}$ Cardiology Clinic, University Clinical Center of Kosova, Kosova
}

Received: 10 February 2020 / Accepted: 20 February 2020 / Publication date: 26 March 2020

Cite as: Rexhepi S, Rexhepi M, Rexhepi B, Sahatciu-Meka V, Mahmutaj V. Bone mineral density in patients of early onset rheumatoid arthritis. Med J Bakirkoy 2020;16(1):44-8

\begin{abstract}
Objective: Rheumatoid arthritis (RA) is a chronic inflammatory and destructive joint disease that affects $0.5-1 \%$ of the world's population and commonly leads to significant disability and consequent impairment of quality of life. Osteoporosis is an early and common feature in RA and occurs during the course of the disease as extra-articular manifestation of rheumatoid arthritis, which may result in increased risk of fractures, morbidity, and mortality. The aim of this study was to evaluate changes in bone mineral density in patients with early-onset rheumatoid arthritis including its correlation with disease activity.

Method: Ther study was performed with 50 patients diagnosied as early-onset rheumatoid made less than two years ago $n$ the Private Clinic "Rheuma", who fulfilled the diagnostic criteria of American College of Rheumatology/ European League Against Rheumatism and 30 healthy volunteers as controls. Bone mineral density of these patients was measured at lumbar spine and hip by using dual energy $x$-ray absorptiometry scan (DEXA Stratos 800). Demographic and clinical data including age, gender, BMI, menstrual status, disease duration, laboratory tests, and disease activity scale (DAS28) scores were collected.

Results: From a total of 50 patients with RA, 36 were females and 14 were males with an overall mean age of 27-57 (33.7 \pm 7.87 years), fulfilling ACR/EULAR Criteria. The patients with RA, had osteoporosis (16\%), osteopenia (65\%) and normal BMD (30\%) values. In the group of RA patients with osteoporosis had higher disease activity scores (DAS-28) without any statistically significant correlation compared to RA patients with normal BMD values or osteopenia.

Conclusion: Patients with RA are more likely to have bone loss compared to normal age subjects. Lower BMD values were found in patients at earlier stage of the rheumatoid arthritis with higher disease activity. Dual energy $x$-ray absorptiometry is an important tool to assess BMD in early RA patients.
\end{abstract}

Keywords: rheumatoid arthritis, osteoporosis, DAS-28, BMD

öz

Amaç: Romatoid artrit (RA), dünyadaki popülasyonun\% 0,5-1'ini etkileyen ve genellikle yaşam kalitesinde önemli bir sakatlığa ve bunun sonucunda bozulmaya neden olan kronik bir enflamatuar ve yıkıcı eklem hastalığıdır. Osteoporoz RA'da erken ve yaygın bir özelliktir. Hastalığın seyri sırasında romatoid artritin ekstra-artiküler belirtisi olarak ortaya çıkar ve bu da kırık, morbidite ve mortalite riskinde artısa neden olabilir. Bu çalışma, erken başlangıçı romatoid artritli hastalarda hastalık aktivitesi ile korelasyonu da dahil olmak üzere kemik mineral yoğunluğu değişikliklerini değerlendirmeyi amaçlamaktadır.

Yöntem: Örnek erken başlangıçlı romatoid olan 50 hastadan oluşmaktadır. Özel Klinik "Romatoloji"de iki yıldan daha az olan artrit, Romatoloji / Amerikan Romatoloji Koleji / Romatizmaya Karşı Teşhis Kriterleri ve 30 sağılılı gönüllü kontrolör olarak yerine getirildi. Bu hastaların kemik mineral yoğunluğu lomber omurga ve kalçada çift enerjili x-ısıını absorpsiyometri taraması (DEXA Stratos 800) ile ölçüldü. Demografik ve klinik veriler yaş, cinsiyet, BKi, adet durumu, hastalık süresi, laboratuvar testleri ve hastalık aktivite ölçeği (DAS28) gibi toplandı.

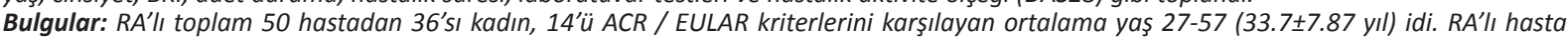
grubunda \% 16'sında osteoporoz, \%65'inde osteopeni ve \%30'unda normal KMY vardı. Osteoporozlu RA hasta grubunda daha yüksek hastalık aktivite skoru (DAS-28) bulundu ve normal BMD ya da osteopeni olan RA hastalarına göre istatistiksel olarak anlamlı bir ilişki yoktu.

Sonuç: RA hastalarının normal yaștaki deneklere göre kemik kaybı yașama olasılığı daha yüksektir. Bulgular, romatoid artritin erken evrelerinde, hastalık aktivitesi yüksek olan hastalarda düşük KMY olduğunu göstermektedir. Erken RA hastalarında KMY'yi değerlendirmek için çok önemli bir araç çift enerjili $x$-ışını absorpsiyometrisi olarak kabul edilir.

Anahtar kelimeler: romatoid artrit, osteoporoz, DAS-28, BMD

Corresponding Author:

blerta.rexhepi@gmail.com
B. Rexhepi 0000-0002-0135-4519

S. Rexhepil 0000-0003-4839-9906

M. Rexhepil 0000-0001-5334-4550

V. Sahatciu-Meka 0000-0003-4061-1888

V. Mahmutaj 0000-0001-7646-3149

$\S$ This study entitled as "Bone Mineral Density in Patients with Early Onset Rheumatoid Arthritis"has been presented by authors as a case report in 2017 IOF-ESCEO World Congress on Osteoporosis

(c) Telif hakkı Sağıı Bilimleri Üniversitesi Bakırköy Dr. Sadi Konuk Eğitim ve Araştırma Hastanesi'ne aittir. Logos Tıp Yayıncılık tarafindan yayınlanmaktadır. Bu dergide yayınlanan bütün makaleler Creative Commons Atff-GayriTicari 4.0 Uluslararası Lisansı ile lisanslanmıştır.

(c) Copyright Health Sciences University Bakırköy Sadi Konuk Training and Research Hospital. This journal published by Logos Medical Publishing.

Licenced by Creative Commons Attribution-NonCommercial 4.0 International (CC BY-NC 4.0) 


\section{INTRODUCTION}

Rheumatoid arthritis (RA) is a chronic inflammatory and destructive joint disease, which affects about $0.5-1 \%$ of the population in the world. It is the most common form of chronic inflammatory arthritis and in many cases it causes joint damage and physical disability. It may also result in a variety of extra-articular manifestations, such as fatigue, formation of subcutaneous nodules, lung involvement, pericarditis, peripheral neuropathy, vasculitis, and hematologic abnormalities ${ }^{(1)}$. As an inflammatory disease, rheumatoid arthritis changes the biomechanical properties of bones, which leads to the alterations in bone components through the increased production of pro-inflammatory cytokines ${ }^{(2)}$. Some studies have found that disease duration, seropositivity for anti$\mathrm{CCP}$, and rheumatoid factor (RF) are associated with bone loss in RA patients ${ }^{(3)}$. Osteoporosis is an early and common feature in RA. It is present during the course of the disease as extra-articular manifestation of rheumatoid arthritis, which may lead to increased risk of fractures, morbidity, and mortality (4). The National Osteoporosis Foundation (NOF) and International Society for Clinical Densitometry (ISCD) have recommended dual-energy $x$-ray absorptiometry (DEXA) testing for women, who are over 65 years old, for patients who have fractures after the age of 50 or if they suffer a fragility fracture, patients on chronic glucocorticoid therapy, and people at high risk of low bone mass, bone loss or fracture, as well as for patients with RA ${ }^{(5)}$. Several studies have found an increased risk of bone loss in patients with rheumatoid arthritis. Patients with rheumatoid arthritis are at increased risk of osteoporosis for various reasons. Thus, to contribute to knowledge development, this study aims to evaluate bone mineral density changes in patients with early -onset rheumatoid arthritis, including its correlation with DAS-28 scores.

\section{MATERIAL and METHODS}

Study Population: This research is a cross-sectional case- control study. The sample comprises of 50 patients with early- onset rheumatoid arthritis (diagnosed within less than 24 months after its onset) and 30 healthy volunteers as controls. All of these patients fulfilled the American College of Rheumatology/European LeagueAgainstRheumatism
EULAR/ACR criteria for RA ${ }^{(6)}$. They were recruited in Private Clinic "Rheuma" in Kosovo. For this study, informed consent was obtained from patients included in this study. DAS-28 scores were measured in order to evaluate RA disease activity. DAS- 28 scores were rated as follows: $\leq 2.6$, disease remission; 2.63.2, low disease activity; 3.3-4.9, moderate disease activity, and $>5.1$, severe disease activity ${ }^{(7)}$. Functional class assessment was conducted by using a validated version of the health assessment questionnaire (HAQ) ${ }^{\left({ }^{8}\right)}$. BMDs were measured for all RA patients at Private Clinic "Rheuma" through dual energy $x$-ray absorptiometry scan (DEXA-Stratos800) at lumbar spine (L1-L4) and proximal femur. World Health Organization (WHO) was used as a basis to diagnose osteoporosis. Osteopenia is defined with BMD between -1.0 SD and -2.5 SD and osteoporosis below $-2.5 \mathrm{SD}^{(9)}$. Laboratory test were conducted, comprising of a full blood count ( $C B C)$, erythrocyte sedimentation rate (ESR, $\mathrm{mm} /$ hour), C-reactive protein (CRP, $\mathrm{mg} / \mathrm{dL}$ ), full blood chemistry, including renal and liver function tests, rheumatoid factor (RF IgM, U/L), and anticyclic citrullinated peptide (antiCCP, $\mathrm{u} / \mathrm{ml}$ ).

Statistical Analysis: The Statistical Program for Social Sciences (SPSS) was used to analyze the data by expressing values as mean and standard deviation. The unpaired t-test for numerical variables was used to analyze the differences between two groups. Categorical variables were analyzed using chi-square test. Spearman correlation test $(r)$ was used for correlations. $P$ values of $>0.05$, were nonsignificant if $P$ values ware $<0.05$, they were considered to be significant predictors. While $P$ values of $<0.001$ denoted high degrees of significance.

\section{RESULTS}

From a total of 50 patients with RA (Group 1), 36 were females and 14 were males with a mean age of $33.7 \pm 7.87$ (range, 27-57) years with a mean disease duration of $15.3 \pm 8.87$ months fulfilling ACR/EULAR criteria. The healthy group of 30 controls (Group 2) comprised 21 females (70\%) and $9(30 \%)$ males, with a mean age of $37.3 \pm 6.37$ (range, 25-51) years. In Group 1, 15 (30\%) and in Group 2, 6 (20\%) study participants were smokers. Thus, Table 1 presents demographic data, DAS- 28 scores, HAQ scores, and results of laboratory tests used in the study. 
Table 1. Demographic, clinical, and laboratory data of patients with RA versus healthy controls.

\begin{tabular}{|c|c|c|c|c|}
\hline Variables & Ra subjects $(n=50)$ & Controls $(n=30)$ & P value & Significance \\
\hline Age (years) mean $\pm \mathrm{SD}$ & $\begin{array}{c}33.7 \pm 7.87 \\
(27-57 \text { years })\end{array}$ & $\begin{array}{c}37.3 \pm 6.37 \\
(25-51 \text { years) }\end{array}$ & $>0.05$ & Nonsignificant \\
\hline \multicolumn{5}{|l|}{ Gender } \\
\hline Female & 36 & $21(70 \%)$ & $>0.05$ & Nonsignificant \\
\hline Male & 14 & $9(30 \%)$ & & \\
\hline \multicolumn{5}{|l|}{ Smoking } \\
\hline Yes & $15(30 \%)$ & $6(20 \%)$ & $>0.05$ & Nonsignificant \\
\hline No & $35(70 \%)$ & $14(80 \%)$ & & \\
\hline Disease duration mean $\pm S D$ and range (month) & $15.3 \pm 8.87$ & & & \\
\hline DAS-28Remission $(\leq 2.4)$ & $6 / 50(12 \%)$ & & & \\
\hline Mild disease activity (2.5-3.6 & $5 / 50(10 \%)$ & & & \\
\hline Moderate disease activity (3.7-5.5) & $29 / 50(58 \%)$ & & & \\
\hline Severe disease activity $(>5.5)$ & $10 / 50(20 \%)$ & & & \\
\hline \multicolumn{5}{|l|}{$\mathrm{HAQ}$} \\
\hline 0-1 (mild disability) & $35 / 50(70 \%)$ & & & \\
\hline 1-2 (moderate disability) & $10 / 50(20 \%)$ & & & \\
\hline 2-3 (severe disability) & $5 / 50(10 \%)$ & & & \\
\hline ESR mean $\pm S D$ & $61.4 \pm 27(14-110)$ & $10 \pm 4$ & $<0.001$ & Highly Significan \\
\hline $\mathrm{CRP}$ mean $\pm \mathrm{SD}$ & $27.3 \pm 12(6-60)$ & 0 & $<0.05$ & Significant \\
\hline
\end{tabular}

Abbreviations: RA: rheumatoid arthritis; DAS 28: Disease activity scale; HAQ: Health Assessment Questionnaire; ESR: erythrosedimentation rate; CRP: C-reactive protein; SD: standard deviation.

The findings suggest that by deploying a modified DAS- 28 scale $12 \%$ (6/50) of RA patients were considered to be in remission, while other had hlow, (6/50:12\%), high (5/50:10\%), moderate (29/50:58\%), and high (10/50: 20\%) disease activities as presented in Table 1. Based on HAQ scores, it was found that RA patients had mild (score 0-1), (35/50: 70\%), moderate (1-2) 10/50 (20\%), and severe (score 2-3) (5/50:10\%) disabilities (Table 1). The empirical results did not reveal any statistically significant correlation between disease duration, DAS28, ESR, and BMD $(p>0.05)$. Moreover, comparison of risk factors for osteoporosis between patients and controls did not show any statistically significant correlation $(p>0.05)$ for the variables as age, gender, and smoking status. Yet, routine laboratory tests revealed a highly statistically significant difference in ESR $(p<0.001)$ and CRP $(p<0.05)$ values between two groups (Table 1$)$. Any statistically significant differences were not found in other routine laboratory tests, such as kidney and liver function tests, and complete blood count. In the group of RA patients with osteoporosis, a higher disease activity score (DAS-28) was found still without any statistically significant correlation compared to RA patients with normal BMD values or osteopenia.

The findings indicate dthat osteoporosis was more common in RA patients who smoked (8/15 (53.3\%)) in comparison to nonsmokers (6/35 (17.1\%)) (Table $3)$. The patients with RA had osteoporosis $(n=8$ : $16 \%)$, osteopenia ( $n=27: 65 \%)$, while 15 (30\%) patients had normal BMD values. While in the healthy control group, 8 cases had osteopenia and 22 cases had normal BMD values (Figure 1). Osteoporosis at all sites was significantly more common in females than in males.

\section{DISCUSSION}

Osteoporosis is a common complication perceived in patients with RA which also affects quality of life ${ }^{(10)}$. The aim of our study was to evaluate changes in BMDs in patients with early -onset rheumatoid arthritis and its correlation with DAS28 scores. The results of our study have shown the presence of an association between RA and osteoporosis. Herein, it was found that our patients had osteoporosis (16\%), 
Table 2. Comparison of lumbar spine and left femur BMD values in patients with RA and healthy controls.

\begin{tabular}{|c|c|c|c|c|c|c|}
\hline \multirow[b]{2}{*}{ T score } & \multicolumn{3}{|c|}{ RA patients $(n=50)$} & \multicolumn{3}{|c|}{ Healthy Controls $(n=30)$} \\
\hline & $\begin{array}{l}\text { Normal BMD } \\
\quad(n=15)\end{array}$ & $\begin{array}{l}\text { Osteopenia } \\
\quad(n=27)\end{array}$ & $\begin{array}{l}\text { Osteoporosis } \\
\quad(n=8)\end{array}$ & $\begin{array}{l}\text { Normal BMD } \\
\quad(n=22)\end{array}$ & $\begin{array}{l}\text { Osteopenia } \\
\qquad(n=8)\end{array}$ & $\begin{array}{l}\text { Osteoporosis } \\
\text { (n) }\end{array}$ \\
\hline Lumbar spine & $17 / 50$ & $24 / 50$ & $9 / 50$ & $22 / 30$ & $8 / 30$ & 0 \\
\hline (L1-L4) & $34 \%$ & $48 \%$ & $16 \%$ & $73.3 \%$ & $26.6 \%$ & $0 \%$ \\
\hline \multirow[t]{2}{*}{ Left femur } & $32 / 50$ & $12 / 50$ & $6 / 50$ & $29 / 30$ & $1 / 30$ & 0 \\
\hline & $64 \%$ & $24 \%$ & $12 \%$ & $96.6 \%$ & 3.3 & $0 \%$ \\
\hline
\end{tabular}

Abbreviations: $B M D$ : bone mineral density; $R A$ : rheumatoid arthritis

BMD normal (T score >-1), osteopenia (T score $\leq-10>-2.5)$, osteoporosis (T score $\leq-2.5)$;

Table 3. Comparison of BMD values in patients with rheumatoid arthritis with demographic data.

\begin{tabular}{|c|c|c|c|}
\hline & \multicolumn{3}{|c|}{ RA patients $(n=50)$} \\
\hline & Normal BMD (n=15) & Osteopenia ( $n=27)$ & Osteoporosis $(n=8)$ \\
\hline \multicolumn{4}{|l|}{ Age } \\
\hline Mean $\pm S D$, years & $30.2 \pm 5.3$ & $38.4 \pm 7.2$ & $45.5 \pm 12.3$ \\
\hline \multicolumn{4}{|l|}{ Disease duration } \\
\hline Mean+SD, months & $8.6 \pm 2.8$ & $11.3 \pm 4.6$ & $16.2 \pm 2.8$ \\
\hline \multicolumn{4}{|l|}{ Gender } \\
\hline Female $(n=36)$ & $8(22.2 \%)$ & $22(61.1 \%)$ & $6(16.6 \%)$ \\
\hline Male $(n=14)$ & $7(50 \%)$ & $5(35.7 \%)$ & $2(14.2 \%)$ \\
\hline \multicolumn{4}{|l|}{ Smoking } \\
\hline Yes (15) & $2(13.3 \%)$ & $5(33.3 \%)$ & $8(53.3 \%)$ \\
\hline No (35) & $17(48.5 \%)$ & $12(34.2 \%)$ & $6(17.1 \%)$ \\
\hline
\end{tabular}

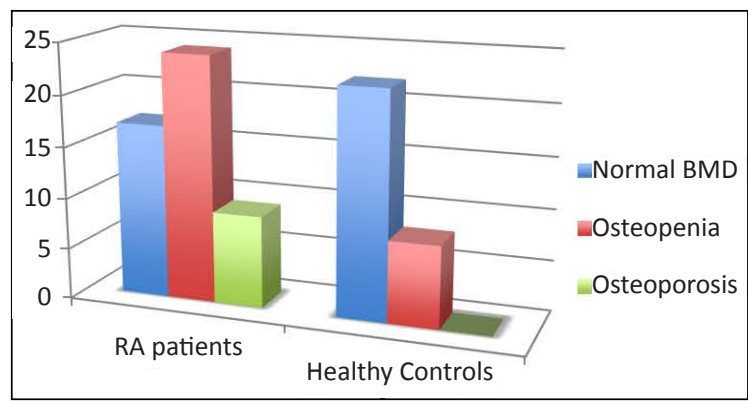

Figure 1. Comparison of BMD values in patients with RA and healthy controls.

osteopenia (65\%), or normal BMD (30\%) values In the healthy control group, the findings have shown that none of them had osteoporosis, while 8 patients had osteopenia, and 22 had normal BMD values. These findings are similar with the study of Brand et al, indicating higher risk of low BMD in RA patients compared to healthy controls ${ }^{(11)}$. A study from Kim et al. emphasized higher risk of osteoporotic fractures in patients with RA in all age groups in both males and females and at various anatomical sites compared to individuals without RA ${ }^{(12)}$. Nevertheless, in our study, osteoporosis at all sites was more common in females than in males, without any statistically significant intergroup difference. Furthermore, in the study of Yoon J et al and in similar studies, gender of the patients was significantly associated with osteoporosis ${ }^{(13)}$. Spine was the most common site of osteoporosis in patients with RA with BMD of $16 \%$, followed by hip with BMD of $12 \%$. The results of our study were similar to those of Güler-Yüksel et al who found that the most common site for osteoporosis in RA patients was the spine (9\%), which is followed by the total hip $(4 \%)^{(14)}$. Yoon et al. showed that osteoporosis in women with RA, younger than 60 years were more prevalent at the lumbar spine than at the femur, but the difference was not statistically significant ${ }^{(15)}$. HAQ scores in our study showed that RA patients with osteoporosis had severe disability. In their study, Sinigaglia et al found significantly higher HAQ scores in RA patients with osteoporosis $(p=0.001)^{(16)}$. 


\section{CONCLUSION}

RA patients are more likely to have bone loss compared to normal age-matched subjects. The findings suggest that patients with lower BMD values at earlier stage of the rheumatoid arthritis had higher disease activities. Disability of patients with RA leads to limitation of physical activity, and reduces bone mineral density. All these factors cause bone loss independent of each other. A crucial tool to assess BMD in early-onset RA patients is considered to be dual energy $\mathrm{x}$-ray absorptiometry.

Ethics Committee Approval: Shërbimi Spilator dhe Klinik Universitar i Kosovës (SHSKUK) Univerzitetska Bolnicka i Klinicka Sluzba Kosova (UBKSK) Hospital and University Clinical Service of Kosova (HUCSK) Qendra Klinke Universitare e Kosovës-Universitetski Klinicki Centar Kosova University Clinical Center of Kosova, Komisioni Etiko Profesional (1581/ 20.06.19).

Conflict of Interest: None declared.

Funding: Private Clinic "Rheuma"

Informed Consent: Informed consent of the patients was obtained.

\section{REFERENCES}

1. Sokka T, Krishnan E, Häkkinen A, Hannonen P. Functional disability in rheumatoid arthritis patients compared with a community population in Finland. Arthritis Rheum. 2003;48:5963.

https://doi.org/10.1002/art.10731

2. Coulson KA, Reed G, Gilliam BE, Kremer JM, Pepmueller PH. Factors influencing fracture risk, $T$ score, and management of osteoporosis in patients with rheumatoid arthritis in the Consortium of Rheumatology Researchers of North America (CORRONA) registry. J Clin Rheumatol. 2009;15:155-60. https://doi.org/10.1097/RHU.0b013e3181a5679d

3. Guler H, Turhanoglu AD, Ozer B, Ozer C, Balci A. The relationship between anti-cyclic citrullinated peptide and bone mineral density and radiographic damage in patients with rheumatoid arthritis. Scand J Rheumatol. 2008;37:337-42. https://doi.org/10.1080/03009740801998812

4. Wijbrandts CA, Klaasen R, Dijkgraaf MGW, Gerlag DM, van
Eck-Smit BLF, Tak PP. Bone mineral density in rheumatoid arthritis patients 1 year after adalimumab therapy: Arrest of bone loss. Ann Rheum Dis. 2009;68:373-6. https://doi.org/10.1136/ard.2008.091611

5. Leib ES, Lewiecki EM, Binkley N, Hamdy RC. Official positions of the International Society for Clinical Densitometry. J Clin Densitom. 2004;7:1-6.

https://doi.org/10.1385/JCD:7:1:1

6. Felson DT, et al. American College of Rheumatology/European League Against Rheumatism provisional definition of remission in rheumatoid arthritis for clinical trials. Arthritis Rheum. 2011;63(3):573-86. https://doi.org/10.1002/art.30129

7. Fransen J, van Riel PLCM. The Disease Activity Score and the EULAR response criteria. Clin Exp Rheumatol. 2005;23(Suppl. 39):S93-9.

8. Van der Heijde DM, van Riel PL, van de Putte LB. Sensitivity of a Dutch Health Assessment Questionnaire in a trial comparing hydroxychloroquine vs. sulphasalazine. Scand J Rheumatol. 1990;19:407-12. https://doi.org/10.3109/03009749009097629

9. WHO. Assessment of fracture risk and its application to screening for postmenopausal osteoporosis: Report of a WHO Study Group. World Health Organization Technical Report Series. 1994;843:1-129.

10. Gough AK, Lilley J, Eyre S, Holder RL, Emery P. Generalized bone loss in patients with early rheumatoid arthritis. Lancet. 1994;344(8914):23-7. https://doi.org/10.1016/S0140-6736(94)91049-9

11. Brand C, Lowe A, Hall S. The utility of clinical decision tools for diagnosing osteoporosis in postmenopausal women with rheumatoid arthritis. BMC Musculoskelet Disord. 2008; $9(1): 13$. https://doi.org/10.1186/1471-2474-9-13

12. Kim SY, Schneeweiss S, Liu J, et al. Risk of osteoporotic fracture in a large population-based cohort of patients with rheumatoid arthritis. Arthritis Res Ther. 2010;12:R154 https://doi.org/10.1186/ar3107

13. Hafez EA, Mansour HE, Hamza SH, Moftah SG, Younes TB, Ismail MA. Bone mineral density changes in patients with recent-onset rheumatoid arthritis. Clin Med Insights: Arthritis Musculoskelet Disord. 2011;4:87-94. https://doi.org/10.4137/CMAMD.S7773

14. Güler-Yüksel M, Bijsterbosch J, Goekoop-Ruiterman YP, et al. Bone mineral density in patients with recently diagnosed, active rheumatoid arthritis. Ann Rheum Dis. 2007;66(11):150812. https://doi.org/10.1136/ard.2007.070839

15. Yoon J, Kwon SR, Lim MJ, et al. A comparison of three different guidelines for osteoporosis treatment in patients with rheumatoid arthritis in Korea. Korean J Intern Med. 2010;25(4):436-46 https://doi.org/10.3904/kjim.2010.25.4.436

16. Sinigaglia L, Nervetti A, Mela $Q$, et al. A multicenter cross sectional study on bone mineral density in rheumatoid arthritis. Italian Study Group on Bone Mass in Rheumatoid Arthritis. J Rheumatol. 2000;27(11):2582-9. 